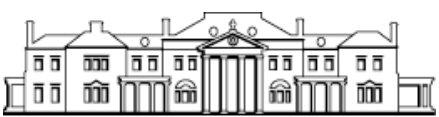

Levy Economics o Institute of Bard College

Working Paper No. 711

\title{
Global Financial Crisis: A Minskyan Interpretation of the Causes, the Fed's Bailout, and the Future
}

by

\author{
L. Randall Wray \\ Levy Economics Institute of Bard College
}

March 2012

\begin{abstract}
*This paper reports research undertaken as part of a Ford Foundation project, "A Research And Policy Dialogue Project On Improving Governance Of The Government Safety Net In Financial Crisis.” The author thanks June Carbone for comments and Andy Felkerson and Nicola Matthews for assistance.
\end{abstract}

The Levy Economics Institute Working Paper Collection presents research in progress by Levy Institute scholars and conference participants. The purpose of the series is to disseminate ideas to and elicit comments from academics and professionals.

Levy Economics Institute of Bard College, founded in 1986, is a nonprofit, nonpartisan, independently funded research organization devoted to public service. Through scholarship and economic research it generates viable, effective public policy responses to important economic problems that profoundly affect the quality of life in the United States and abroad.

Levy Economics Institute

$$
\text { P.O. Box } 5000
$$

Annandale-on-Hudson, NY 12504-5000

http://www.levyinstitute.org

Copyright (C Levy Economics Institute 2012 All rights reserved

ISSN 1547-366X 


\begin{abstract}
This paper provides a quick review of the causes of the Global Financial Crisis that began in 2007. There were many contributing factors, but among the most important were rising inequality and stagnant incomes for most American workers, growing private sector debt in the United States and many other countries, financialization of the global economy (itself a very complex process), deregulation and desupervision of financial institutions, and overly tight fiscal policy in many nations. The analysis adopts the "stages" approach developed by Hyman P. Minsky, according to which a gradual transformation of the economy over the postwar period has in many ways reproduced the conditions that led to the Great Depression. The paper then moves on to an examination of the US government's bailout of the global financial system. While other governments played a role, the US Treasury and the Federal Reserve assumed much of the responsibility for the bailout. A detailed examination of the Fed's response shows how unprecedented — and possibly illegal — was its extension of the government's "safety net" to the biggest financial institutions. The paper closes with an assessment of the problems the bailout itself poses for the future.
\end{abstract}

Keywords: Hyman Minsky; Global Financial Crisis; Financialization; Money Manager Capitalism; Bank Bailout; Quantitative Easing; Financial Crisis Inquiry Report; Fraud; Minsky Moment; Real Estate Bubble; MERS; Federal Reserve

JEL Classifications: B31, E30, E32, E50, G21 
This paper will begin with a quick overview of the causes of the Global Financial Crisis (GFC) that began in 2007. There were many contributing factors, but among the most important were rising inequality and stagnant incomes for most workers in America, growing private sector debt in the United States and many other countries, financialization of the global economy (itself a very complex process), deregulation and desupervision of financial institutions, and overly tight fiscal policy in many nations. We then move to an examination of the US government's bailout of the global financial system. While other governments played a role (some smaller governments bailed out their own financial institutions, and the UK government as well as the European Central Bank-ECB — assisted institutions across borders), the US Treasury and the Federal Reserve Bank (Fed) assumed much of the responsibility for the bailout.

It will be argued that the manner in which the rescue was formulated ensured that virtually none of the fundamental problems exposed by the GFC would be addressed. Indeed, it can be plausibly argued that the bailout has made the global financial system much more fragile and has exacerbated the other problems with the US economy that brought on the financial collapse. Further, the GFC and policy adopted in its aftermath have (finally) exposed the fundamental weaknesses of the arrangements of the European Monetary Union (EMU). Another GFC is highly likely, and this time it could well begin in the EMU and then spread quickly to the US - the reverse of the transmission we saw in 2007.

Obviously, this short contribution can provide only an introduction to each of these issues. Because the explanation of the causes is complex and crucial for understanding why the bailout actually made things worse, most of the paper will be devoted to that topic.

\section{CAUSES OF THE COLLAPSE}

The Financial Crisis Inquiry Report ${ }^{1}$ makes a strong case that the crisis was foreseeable and avoidable. It did not "just happen" and it had nothing to do with "black swans with fat tails." It was created by the biggest banks under the noses of our "public stewards.” The GFC represents a dramatic failure of corporate governance and risk management, in large part a result of an unwarranted and unwise focus on trading (actually, gambling) and rapid growth (a good indication of fraud, as William Black argues). We could go farther than the Report and note that

\footnotetext{
${ }^{1}$ The Financial Crisis Inquiry Report, final report of the National Commission on the causes of the financial and economic crisis in the United States.
} 
in all this, the biggest banks were aided and abetted by government "regulators" and "supervisors" who not only refused to do their jobs, but indeed continually pushed for deregulation and de-supervision in favor of "self regulation” and "self supervision.” While many want to blame the crisis on "liquidity" problems, the liquidity crisis bore no relation to an “irrational” bank run, but instead reflected an accurate appraisal of financial institution insolvency. That, in turn, can be attributed to catastrophic reductions of lending standards and to pervasive fraud.

While the Report does "name names” and accurately identifies practices and even individuals that are culpable, I do find some merit in the complaint made by the Republican minority report as well as by some reviewers (most notably Joe Nocera) that there is some danger in focusing on "bad actors," bad financial practices and "bad events." ${ }^{2}$ To be sure, it is a scandal that those most responsible for the crisis - that is to say, top management at the biggest banks and "shadow banks" - have not faced prosecution. And as I will discuss, the way the bailout was handled ensures that another financial crisis is a matter of "when," not "if.” Still, it is important to understand longer term trends. We need to put the crisis in the context of the long-term postwar transformation of the financial system. In that sense, I would argue that even if the "apples” were not bad, the system was.

For that reason, I would deviate from the Report's conclusion: financial fragility had grown on trend, making "it” (in the words of Hyman Minsky, referring to a Fisher-type debt deflation process) likely to "happen again." For that reason, we need to understand the “Minskyan” transformation. I take the position that while the GFC was not strictly inevitable, the financial structure made a crisis highly probable. In many important respects, we had produced conditions similar to those that existed on the eve of the "Great Crash" —and we experienced a similar crisis. The most important difference, however, was the response. While we emerged from the Great Depression with a robust financial system, strict regulation, and strong safety nets, as of spring 2012 we have only managed to prop up the financial institutions that caused the crisis-and have left the economy in a much weaker state than it had been in either 2006 or 1940.

\footnotetext{
${ }^{2}$ See Joe Nocera, “Inquiry is Missing Bottom Line,” The New York Times, January 26, 2011 www.nytimes.com/2011/01/29/business/29nocera.html; Gretchen Morgenson, “A Bank Crisis Whodunit, With Laughs and Tears,” The New York Times, January 29, 2011 http://www.nytimes.com/2011/01/30/business/30gret.html. The Dissenting Views of the FCIC are contained in the Report from page 411; FCIC (2011: 411).
} 


\section{The Minsky Moment}

When the GFC struck, many commentators called it the "Minsky Crisis” or "Minsky Moment," after the economist Hyman Minsky who had developed a famous "financial instability hypothesis" that described the transformation of an economy from a "robust" financial structure to a “fragile” one. ${ }^{3}$ A “run of good times” would encourage ever-greater risk-taking, and growing instability would be encouraged if financial crises were resolved by swift government intervention (Kregel 2008). As Minsky insisted, "stability is destabilizing”4_and this seemed to perfectly describe the last few decades of US experience, during which financial crises became more frequent and increasingly severe. We could list, for example, the Savings and Loan crisis of the 1980s, the stock market crash of 1987, the Developing Country debt crises (1980s, early 1990s), the Long Term Capital Markets and Enron fiascoes, and the Dot-Com collapse. ${ }^{5}$

Each of these led to US government intervention that prevented a downward spiral of financial markets or of the economy (although in some cases, recessions followed the crises); indeed, after the Dot-Com crisis, the belief that a new "Great Moderation”6 had taken hold in the US, making serious downturns impossible. All of this encouraged more risk, more financial layering and leveraging (debt issued against debt, with little net worth backing it up). So, it is completely appropriate to give credit to Minsky’s foresight.

\section{Minsky’s Stages Approach}

But Minsky’s theory had actually gone much farther than this—-he had developed a "stages” approach to describe the long-term transformation of the financial system since the late $19^{\text {th }}$ century. ${ }^{7}$ It is not necessary to go into this in detail-let us just briefly describe the three main stages. In the early $20^{\text {th }}$ century, a form named “finance capitalism” by Rudolf Hilferding took form, dominated by investment banks that provided the finance for corporations (Hilferding 1981 [1910]). However, by the late 1920s, these were mostly financing speculation in financial

\footnotetext{
${ }^{3}$ See Sen (2010) and John Cassidy, “The Minsky Moment,” The New Yorker, February 4, 2008. http://www.newyorker.com/talk/comment/2008/02/04/080204taco_talk_cassidy

${ }^{4}$ What Minsky means by this is that apparent stability encourages more risk-taking by investors, financial institutions, and entrepreneurs. They tend to borrow more relative to expected earnings, and innovate with riskier financial instruments. In addition, regulators might relax rules on the belief that downside risks have been reduced. All of this increases financial fragility and hence enhances instability.

${ }^{5}$ See Wray (2009) and Minsky (1991).

${ }^{6}$ See Bernanke (2004).

${ }^{7}$ See Wray (2009).
} 
assets, particularly in equities issued by subsidiary trusts of the investment banks themselves. In truth, these were little more than pyramid schemes-speculating in essentially worthless shares, much like the infamous schemes of Charles Ponzi or the modern day Bernie Madoff. Goldman Sachs played a prominent role in the scams, and warranted a whole chapter in the best account of the 1929 "Great Crash”" by economist John Kenneth Galbraith.

In any event, in Minsky’s view, the Great Depression ended the finance capitalism stage and ushered in a much more stable version with the New Deal reforms of the financial sector, plus a much bigger role for the federal government in managing the economy. Minsky called this "managerial-welfare state” capitalism, where the "Big Bank" (Fed) and "Big Government" (Treasury) promoted stable economic growth, high employment, and rising wages and falling inequality. The US entered its economic "golden age,” which lasted from the end of World War II through the early 1970s.

The problem is that the absence of deep recessions and severe financial crises encouraged innovations that increased financial instability. ${ }^{9}$ Further, for reasons we won’t explore, conservative politicians and economists were able to slowly chip away at the New Deal reforms that promoted growth while providing social protection. After 1974, median male earnings stopped growing and began to fall ${ }^{10}$ as workers lost effective representation by unions, the social safety net was gutted, and unemployment came to be seen as a desirable outcome-a tool used by policy-makers to keep inflation down. Financial institutions were deregulated and de-supervised $^{11}$, and their power grew in a self-reinforcing manner: as they were able to capture a greater share of profits, their political power increased making it possible to further subvert or eliminate regulations so that they could gain an even larger share of profits.

There are many aspects to this transformation, and Minsky was certainly not the only one to notice it. Some called it "casino capitalism,” many identified it as "financialization" (Strange 1997; D’Arista 2001). In important respects, it was similar to Hilferding's “finance

\footnotetext{
${ }^{8}$ See Galbraith (2009 [1954]).

${ }^{9}$ For an overview of Minsky’s approach, see Papadimitriou and Wray (1998).

${ }^{10}$ A study by the Brookings Institute shows that median earnings of men peaked around 1974, and have since declined significantly (for men as a whole, by 28 percent relative to 1969). See Michael Greenstone and Adam Looney, “Have Earnings Actually Declined?” The Brookings Institute, March 4, 2011. http://www.brookings.edu/opinions/2011/0304_jobs_greenstone_looney.aspx

${ }^{11}$ There have been several important legislative actions to reduce regulation, among which the most important were the Depository Institutions Deregulation and Monetary Control Act of 1980 and the Garn-St. Germain Depository Institutions Act of 1982 that freed the thrifts, and the Gramm-Leach-Bliley Act of 1999 that ended Glass-Steagall separation of investment banking from commercial banking, However, also important were changing approaches by regulators and supervisors to their roles, with much greater reliance on self-supervision by financial institutions.
} 
capitalism" - with what were called "nonbank banks," or "shadow banks," rising to challenge the commercial banks. ${ }^{12}$ This development also provided justification for dropping the New Deal reforms so that the banks could “compete” with the new intruders who were poaching business. Again, this is a huge topic, but the important point is that even as shadow banks pushed financial practice to new frontiers, the commercial banks insisted that they had to follow suit.

And many, if not most, of the new practices served no social purpose beyond making top management of financial institutions incredibly rich. ${ }^{13}$ At the same time, the structure of incentives and rewards was changed such that risky bets, high leverage ratios, and short-term profits were promoted over long-term firm survival and returns to investors. A good example of the transformation was the conversion of the venerable investment banks like Goldman Sachs from partnerships to publicly held firms with hired and richly rewarded management. While the structure was somewhat different, the results were similar to those that led up to the "Great Crash” in 1929_ “pump and dump” incentives were created through which management would “pump” asset and equity prices, and then sell out (“dump”) their own positions before the speculative boom collapsed. What we see by the early 2000s is the coalescence of three different phenomena that made the biggest financial institutions extremely dangerous: (1) the

\footnotetext{
${ }^{12}$ New Deal legislation and the corresponding regulations that implemented the new laws tightly regulated the commercial banks, limiting, for example, the banks' ability to offer interest on checking accounts, and providing deposit insurance that guaranteed the safety of consumer accounts. (See the Banking Act of 1933 and the National Housing Act of 1934, which established insurance and rules for thrifts.) The legislation did not, however, prohibit other financial institutions - including investment banks plus a wide variety of other kinds of financial institutions that engaged in activities closely related to banking, called "nonbank banks" or "shadow banks;" see FCIC (2011): Chapter 2. Repeatedly, in the face of such developments, Congress and federal regulators have eased the restrictions on regulated entities (such as limits on interest rates) rather than restrict the activities of the unregulated, undermining the stability inducing provisions of the original New Deal legislation. The FCIC Report discusses some of the deregulation in Chapter 4. The rise of subprime lending is in Chapter 5, and discussion of securitization and derivatives is covered in Chapter 3.

${ }^{13}$ Indeed, many of the most celebrated "advances" have been the most subject to abuse. Both "junk bonds" and mortgage backed securities, for example, were hailed as ways to limit risk through various types of portfolio diversification. In both cases, however, the greater complexity of the transactions necessary to diversify the holdings made it easier to disguise market manipulation, customer deception, or outright fraud. For these new products to deliver their supposed advantages without undermining market stability would have required much greater oversight than the relatively more transparent transactions that preceded them. In contrast, the New Deal reforms promoted stability by limiting commercial banks to activities that could be easily supervised — the distribution of toasters is much easier to oversee than a market for collateralized debt obligations (CDOs). Some of the innovations had nothing to do with extending credit, but rather allowed speculators to bet on failure of debtors to make promised payments; others allowed speculators to bet on inflation of food prices. As if it were not bad enough, speculation in these types of instruments could sometimes influence markets in a self-fulfilling manner: by betting on bankruptcy, speculators caused borrowing costs to rise and ensured that default was more likely. The FCIC Report provides very useful summaries of several of the innovations-in particular, of credit default swaps (CDSs) and synthetic collateralized debt obligations. Both of these were extremely important in allowing unregulated casino-type betting against US real estate.
} 
return of "pump and dump” strategies, ripping off customers and shareholders; (2) the move from partnerships to corporate form, which increases the agency problems (institutions run in the interests of management, not owners); and (3) excessive executive compensation that was tied to short-term performance, which increases the pressures to "cheat" or to do anything else that justifies huge bonuses.

\section{Money Manager Capitalism}

Minsky called this new stage “money manager capitalism.” This draws attention to a characteristic feature: huge pools of funds under management by professionals-pension funds, sovereign wealth funds, hedge funds, university endowments, corporate treasuries, and so on. Every money manager had to beat the average return to retain clients, something that is, of course, statistically impossible. But with such incentives and with virtually no government regulation or oversight, this encouraged not only risky behavior but also ethically compromised actions. In Minsky's view, the rise of these managed funds was due to the success of the earlier managerial-welfare state capitalism: the absence of depressions and relatively good growthplus policies that favored private pensions_-allowed financial wealth to grow over the entire postwar period. Although financial crises came along and wiped out some wealth, each crisis was contained so that most wealth survived, and quickly resumed growth.

What was really important was the dynamic created by the shift of power away from banks to the very lightly regulated "money managers" at the "shadow banks" (Nersisyan and Wray 2010). To compete, banks needed to subvert regulations through innovations and then to have them legislatively eliminated. This allowed banks to increase leverage ratios, and thus risk, to keep pace with shadow banking practice. There was a “Gresham’s Law” in operation: those institutions that could reduce capital ratios and loss reserves the most quickly were able to increase net earnings and thus rewards to management and investors. Further, there was a shift to maximization of share prices as one of the main goals of management-which supposedly aligned the interests of shareholders and top managers who received stock options in compensation. That, in turn, encouraged short-term focus on performance in equity markets, which — as we discovered in 1929—is accomplished through market manipulation (both legal and illegal) (Veblen 1958; Galbraith 2009 [1954]) .

The problem was that the sheer volume of financial wealth under management outstripped socially useful investments. To keep returns high, money managers and bankers had 
to turn to increasingly esoteric financial speculation - in areas that not only did not serve the public purpose, but actively subverted it. An example would be the rise of index speculation in commodities markets that drives up global prices of energy and food leading to hunger and even starvation around the world. The Dot-Com bubble is another example-speculators drove up the prices of stocks of internet companies with no business model or prospective profits. The inevitable crash wiped out hundreds of billions of dollars of wealth.

\section{Fraud and the US Real Estate Bubble}

Another example is the US real estate boom that began before 2000 and finally collapsed in 2007, triggering the GFC. ${ }^{14}$ It was the biggest speculative boom in US history, and was driven by money managers who created complex securities and derivatives for speculative bets (Wray 2008a; 2008b). Nothing is more emblematic of the speculative excess than the special collateralized debt obligations created by Goldman Sachs to allow a hedge fund managed by John Paulson to bet against homeowners and the holders of securitized mortgages. Briefly, Goldman let Paulson hand-pick the riskiest mortgages to put into securities that would be purchased by investors such as pension funds. ${ }^{15}$ Goldman then created CDOs that would pay off if the homeowners were not able to make their mortgage payments, meaning the securities the investors bought would fall in value. The investors would lose, the homeowners would lose their homes, and Paulson would win! Goldman, of course, won too-it got fee income for creating the securities and also for creating the instrument that let Paulson win. Goldman also placed lots of bets for its own account against American homeowners. And, finally, it was this demand by investment banks and other speculators for risky instruments on which they could

\footnotetext{
${ }^{14}$ See US Senate (2011).

${ }^{15}$ See Jesse Eisinger and Jake Bernstein, “The Magnetar Trade: How One Hedge Fund Helped Keep the Bubble Going,” ProPublica, April 13, 2010. http://www.propublica.org/article/the-magnetar-trade-how-one-hedge-fundhelped-keep-the-housing-bubble-going. See, also, FCIC (2011): Chapter 8. For other similar reports, see Christine Harper, "Taxpayers Help Goldman Reach Height of Profit in New Skyscraper," Bloomberg.com, April 17, 2010 www.bloomberg.com/apps/news?pid=20670001\&sid=aaLwI2SKYQJg; Peter J. Henning and Steven M. Davidoff, “Goldman Fraud Case Holds Risks For Both Sides,” Deal Book, The New York Times, April 162010 http://dealbook.nytimes.com/2010/04/16/goldman-fraud-case-holds-risks-for-both-sides/; and a series by Gretchen Morgenson and Louise Story, "Banks Bundled Bad Debt, Bet Against It, and Won,” The New York Times, December 24, 2009 http://www.nytimes.com/2009/12/24/business/24trading.html?pagewanted=all; "Investor Who Made Billions Is Not Target of Suit,” The New York Times, April 16, 2010 http://www.nytimes.com/2010/04/17/business/17abacus.html; "SEC Accuses Goldman of Fraud in Housing Deal," The New York Times, April 16, 2010 http://www.nytimes.com/2010/04/17/business/17goldman.html; Gretchen Morgenson, “Exotic Deals Put Denver Schools Deeper in Debt,” The New York Times, August 5, 2010 http://www.nytimes.com/2010/08/06/business/06denver.html?pagewanted=all.
} 
place bets that generated the risky "subprime” and "Alt A" mortgages that eventually brought on the GFC.

The reader should not be misled. While the discussion so far might sound like behavior was merely ethically questionable, in truth, fraud was involved at every step in the "home finance food chain” (Wray 2008a ). The mortgage broker was rewarded for putting prospective homeowners into mortgages with the worst possible terms. Brokers often doctored the documents after signing - to make the terms even worse. Property appraisers were rewarded for overstating property values (so that mortgages would be larger than they should have been). The biggest financial institutions created the Mortgage Electronic Registry System (MERS) to defraud county recorders out of the fees paid to register owners of property; MERS then separated the mortgage "note" from the "deed," destroying a clear chain of title (whether that was intended we do not know) as it cut corners. ${ }^{16}$ The mortgage securitizers (investment banks) issued false "reps and warranties" in their descriptions of the mortgages backing the securities, and frequently failed to follow rules regarding the securitization process itself (the Trustees apparently falsely asserted they held the mortgages — which in most cases were held by servicers, or intentionally destroyed). Mortgage servicers hired "robo-signers" to manufacture documents needed for foreclosures; often they "lost” payments and falsely claimed that borrowers were delinquent, and they even tried to foreclose on homeowners with no mortgage. ${ }^{17}$ Accountants signed-off fudged balances.

And that really is only the tip of the iceberg. It would not be too extreme to say that fraud has become normal business practice in the financial sector. Even though the administration of President Obama has refrained from going after top management, the banks have been forced to pay fine after fine and most of the attorney generals of the fifty states are taking action. ${ }^{18}$

\footnotetext{
${ }^{16}$ See L. Randall Wray, "Requiem for MERS (and the Banks That Created the Frankenstein Monster,” The Huffington Post, January 24, 2011 http://www.huffingtonpost.com/l-randall-wray/requiem-for-mers-and-the-_b 812940.html and L. Randall Wray, "Why Mortgage-Backed Securities Aren't (Backed by Securities): How MERS Toasted the Banks," The Huffington Post, December 30, 2010 http://www.huffingtonpost.com/l-randall-wray/why-mortgagebackedsecuri_b_802600.html.

${ }^{17}$ For an example, see Alice Gomstyn, "No Mortgage, Still Foreclosed? Bank of America Sued for Seizing Wrong Homes,” ABC News, January 25, 2010 http://abcnews.go.com/Business/bank-america-sued-foreclosing-wronghomes/story?id=9637897\#.TzVsRsiSWeU.

${ }^{18}$ Unfortunately, they seem to have caved to pressure; see L. Randall Wray, "State AGs Cave to Banksters," EconoMonitor (blog), February 9, 2012 http://www.economonitor.com/lrwray/2012/02/09/state-ags-cave-tobanksters-2/. See, also, FCIC (2011): Chapter 22 for a discussion of the foreclosure crisis.
} 


\section{Shredding of the New Deal Reforms and Rise of Insecurity}

Minsky also linked rising economic insecurity to the money manager phase. ${ }^{19}$ In the 1960 s, he paradoxically argued against the Kennedy-Johnson War on Poverty because it emphasized welfare and training over job creation. Further, unlike most Keynesian economists, he opposed policy to promote investment and other business-friendly policies that sought to achieve full employment by "pumping” aggregate demand—such as "military Keynesianism” that would stimulate spending in the defense sector. He never believed the "rising tide lifts all boats" story. ${ }^{20}$ Instead, he wanted targeted spending, New Deal-style government job creation (modeled after the Works Progress Administration that created 8 million jobs), and support for consumption by workers.

First, he worried that the typical "Keynesian" policies would generate inflation long before they created full employment because they would create employment and output bottlenecks in the most advanced sectors (i.e.: the defense industries, which are heavily unionized and oligopolistic). The inflation, in turn, would induce "stop-go" policy, with government purposely slowing growth and raising unemployment each time inflation increased. Second, and related to this, the already well-off workers would see income gains, increasing inequality among workers. And, finally, he argued that offering welfare and training to the unemployed is unnecessarily defeatist, and puts "the cart before the horse." It essentially tells the poor and unemployed that they must improve their skills, education, training, and even their character before they can get a job (thus, the War on Poverty was consistent with the "culture of poverty” thesis of Daniel Patrick Moynihan ${ }^{21}$ ). And it would train people for jobs that don't exist. For those reasons, he wanted a universal jobs program (he called it "employer of last resort") - government would guarantee a job offer at the minimum wage for anyone willing to work. He calculated that providing just one minimum wage, full-time job to each poor household would lift two-thirds of families out of poverty. In conclusion, he argued that the War on Poverty without a major job creation component would fail to reduce poverty.

\footnotetext{
${ }^{19}$ See Minsky and Whalen (1996) and Minsky (1996).

${ }^{20}$ See Minsky (1965), Wray (2003), and Kelton and Wray (2004).

${ }^{21}$ See Moynihan (1965).
} 
Time would prove him correct-excluding elderly people on Social Security, there was no significant reduction of poverty rates during the War on Poverty years. ${ }^{22}$ In any case, inequality began to rise, along with trend increases to the unemployment rate- at least until the boom-and-bust cycle that began with President Clinton. After a decade with some improvement of some social measures (during 1996-2006, unemployment trended somewhat lower, economic growth was a bit better, and poverty stopped rising), the GFC caused massive unemployment, increased poverty, and boosted inequality to record levels.

\section{Financial Bubbles, Goldilocks Growth, and Government Budgets}

As mentioned above, the financial sector grew relative to the nonfinancial sectors (manufacturing, agriculture, and nonfinancial services including government spending)—by the time of the GFC, the financial sector accounted for 20 percent of US national value added and 40 percent of corporate profits (Nersisyan and Wray 2004). By itself, it was an autonomous source of growth and also of rising inequality due to high compensation in the sector. Up to half of the college graduates from the elite colleges went into the financial sector because rewards there were far higher than in other sectors. ${ }^{23}$ Compensation at the very top quite simply exploded.

This was at least implicitly recognized by the time of the Clinton administration-with worker income lagging behind, and with loss of US manufacturing jobs, the financial sector played a big role in the Clinton recovery of the 1990s. Indeed, economic growth was sufficiently robust and the boost to income at the very top caused federal government tax revenues to grow swiftly (it was called the Goldilocks economy_fast enough to create jobs but not so rapid as to generate inflation) (Godley and Wray 1999). The federal government's budget went into significant surplus for the first time since the late 1920s. While most economists thought that was good and praised President Clinton's projection that the surpluses would continue for at least 15 years, allowing all federal debt to be retired, a few of us at the Levy Economics Institute (Minsky’s research home until his death in 1996) argued that the surplus would be short-lived. ${ }^{24}$ And that it would kill the boom and cause a deep recession.

\footnotetext{
${ }^{22}$ See Kelton and Wray (2004).

${ }^{23}$ See the NPR report, “Stopping the ‘Brain Drain' of the US Economy,” NPR, February 6, 2012 http://www.scpr.org/news/2012/02/06/31135/stopping-the-brain-drain-of-the-us-economy/

${ }^{24}$ See, for example, Wray (1999).
} 
Here's why. Wynne Godley at the Levy Institute had developed a "three balances" approach to macro analysis based on the accounting identity that the sum of the balances of the domestic private sector, the government sector, and the foreign sector must be zero (Godley and Wray 1999). While any one of these could run a surplus, at least one of the others would have to run a deficit. In the case of the US, by the late 1990s the government sector was running a surplus of about 2.5 percent of GDP, the foreign balance was 4 percent of GDP (meaning the US was running a trade deficit so the rest of the world had a surplus), and so by identity, the US private sector (firms plus households) had a deficit of 6.5 percent (the sum of the other two). In other words, the private sector was spending \$106.50 for every hundred dollars of income. Each year that the private sector spent more than its income, it went more deeply into debt.

This was in some sense the "ugly" side of money manager capitalism: the growth of financial assets under management was equal to the growth of financial liabilities of somebody. (For every financial asset there is an equal financial liability.) We were sure the private sector debt load would become too great, and when spending fell the economy would slip into recession. That, in turn, would cause job losses and force defaults on some of the debt. We believed that would set off a severe financial crisis.

At the beginning of 2000, that appeared to be happening, but the crisis was not as severe as we expected. The private sector retrenched—spending less than its income-and the Clinton budget surpluses morphed into deficits. The Dot-Com bubble went bust and stock markets tanked. The Fed responded by lowering interest rates as the big budget deficits helped to restore economic growth. And then something amazing happened: the American consumer started borrowing again - at a pace even greater than during the Clinton boom. Much of that was to finance housing purchases and to buy big-ticket consumer items financed through "cash-out equity finance”- taking out second mortgages against homes. In other words, the US real estate boom had started. So, as it turned out, for a period of ten years, US households spent more than their incomes, with only the brief respite in the recession of 2000. Nothing like this had ever happened before. And it was aided and abetted by the practices of the money managers discussed above, inducing homeowners to go deeply into risky mortgage debt.

By 2007, the US ratio of debt to GDP reached an all-time peak of 500 percent, or, five dollars of debt to service out of each dollar of income (Nersisyan and Wray 2010). While much discussion in recent months has been about the government debt ratio, the debt of the household sector as well as of nonfinancial business and financial business were all much higher as a 
percent of GDP. Nonfinancial business debt was actually not a huge problem, as much of this was due to long-term finance of capital equipment-and after 2000, US nonfinancial businesses actually did not borrow much. Household debt was a huge problem, of course, and still weighs heavily on consumers, preventing recovery. But what was particularly unusual, and had long been ignored, was the unprecedented rise of financial sector indebtedness, which reached almost 125 percent of GDP. ${ }^{25}$

The biggest political problem created from the experience of the Clinton years is that the wrong lesson was learned. The Clinton administration and many Democrats continue to believe that the budget surpluses were good for the economy; indeed, they argue that the Goldilocks growth was caused by surpluses. They point to the Bush deficits that followed the recession in 2000 as an example of mismanagement of the budget. And so when the GFC hit the economy, they joined with Republicans in keeping the fiscal response too small. ${ }^{26}$ When the economic slowdown lowered tax revenues, the new Obama administration saw the budget deficit explode to 10 percent of GDP — highest since WWII. This generated a hysteria about deficits that made it impossible to get support for stimulus on the necessary scale. As a result, the economy would not recover.

\section{Financialization, Layering, and Liquidity}

There is one final aspect of the rise of money manager capitalism that we need to understand. Above we mentioned that the financial sector's debt reached 125 percent of GDP. This is the debt of one financial institution to another. Most of it was very short-term, even overnight. This is the "financialization" and "layering" that many economists now recognize: debt on debt on debt. What financial institutions had done was to shift the source of finance from deposits (household checking accounts and saving accounts) to financing positions in assets by issuing mostly short-term, non-deposit liabilities held by financial institutions. As an example, a bank would purchase mortgage-backed securities (MBSs) by issuing commercial paper; the commercial paper in turn would be bought by a money market mutual fund (MMMF) that issued deposit-like liabilities to firms and households.

\footnotetext{
${ }^{25}$ See D’Arista (2001); Nersisyan and Wray (2010).

${ }^{26}$ For an examination of behind-the-scenes policy-making during the crisis, see Noam Scheiber, "Obama's Worst Year: The Inside Story of His Brush With Political Disaster,” The New Republic, February 10, 2012 http://www.tnr.com/article/politics/100595/obama-escape-artist-excerpt?page=0,0
} 
Here's the problem. Household bank deposits are insured by the government (FDIC insurance), and banks have essentially unrestricted access to the Fed should they need to cover withdrawals. As such, runs on bank deposits are virtually a thing of the past- they almost never happen in the US any more. So bank deposits are a very stable funding source for banks that buy MBSs or other assets. When US mortgage markets tanked and bad reports were coming out about crashing market values of MBSs, households did not need to worry about their insured deposits. But the MMMFs worried about the uninsured commercial paper issued by banks_-if the MBS assets were bad, the commercial paper was bad, too. That led to a run out of commercial paper, meaning banks had trouble refinancing their positions - and they could not simply sell the MBSs because there was no market for them.

Finally, the holders of "deposits" in MMMFs did run out of them, because they were not insured (Ricks 2011). Suddenly there was a "liquidity crisis"—a run into the most liquid and safe assets (insured deposits plus federal government debt) and a run out of almost everything else. Since financial institutions relied so much on borrowing from each other, and because they no longer trusted each other, the entire global financial system froze. Without government intervention, all financial institutions would have to "sell out position to make position," as Minsky put it, meaning sell their assets because they could no longer finance them. And that would lead to a debt deflation dynamic, because with no buyers, prices of financial assets would collapse. That is precisely what had happened in the 1930s.

\section{THE BAILOUT}

As in the case of the causes of the GFC, the details of the response by governments are complex and numerous. I will not go through the fiscal stimulus packages adopted by the US and other nations. These helped to put a floor on aggregate demand, preventing the deep recession from worsening into another great depression. However, among the large countries, only China mounted an effort that was sufficiently large enough to pull itself out of the downturn. In the US and other countries, the fear was that too much fiscal response would worsen deficits and burden the nations with debt. In truth, the deficits exploded, anyway, as plummeting spending and income destroyed tax revenues. Further, for reasons we cannot go into, these fears about sovereign deficits and debts were misplaced for nations like the US, UK, and Japan that issue their own currencies (Wray 2007). Let us turn, however, to the Fed's response-which, except 
for the 800 billion dollar fiscal stimulus package allocated to Treasury, was left to clean up the mess.

\section{Liquidity or Solvency Crisis?}

It has been recognized for well over a century that the central bank must intervene as "lender of last resort” in a crisis. Walter Bagehot explained this as a policy of stopping a run on banks by lending without limit, against good collateral, at a penalty interest rate. ${ }^{27}$ This would allow the banks to cover withdrawals so the run would stop. Once deposit insurance was added to the assurance of emergency lending, runs on demand deposits virtually stopped. However, as discussed, banks have increasingly financed their positions in assets by issuing a combination of uninsured deposits plus very short-term non-deposit liabilities (such as commercial paper). Hence, the GFC actually began as a run on these non-deposit liabilities, which were largely held by other financial institutions. Suspicions about insolvency led to refusal to roll-over short term liabilities, which then forced institutions to sell assets (Wray 2008a). In truth, it was not simply a liquidity crisis, but rather a solvency crisis brought on by all the risky and fraudulent practices. $^{28}$

Not only did all "finance" disappear, but there was also no market for the trashy assetsso there was no way that banks could sell assets to cover "withdrawals" (again, these were not normal withdrawals by depositors but rather a demand by creditors to be paid). As markets turned against one institution after another, financial institution stock prices collapsed, margin calls were made, and credit ratings agencies downgraded securities and other assets. The big banks began to fail.

It is important to note here that the solvency problems were largely limited to a handful of financial institutions - the biggest ones, including the top half dozen banks, the big investment banks, a few big mortgage lenders, and the big money market mutual funds. All but the MMMFs had been heavily involved in the risky and often fraudulent activities; the MMMFs got in trouble because they held the commercial paper of these (likely) insolvent institutions. The vast majority of US banks were not holding the trashiest assets, although some had made what would turn out to be risky home equity loans and commercial loans. In most cases, for all

\footnotetext{
${ }^{27}$ For a critical analysis of interpretations of lender of last resort functions, see Todd (2002).

${ }^{28}$ See Edward Harrison, “Mervyn King: 'Systemic Insolvency Is Now The Problem,'” Credit Writedowns, December 17, 2010 http://www.creditwritedowns.com/2010/12/mervyn-king-systemic-insolvency-is-now-theproblem.html
} 
but the biggest financial institutions, it was the GFC and then the deep recession that created problems with their loans.

Government response to a failing, insolvent bank is supposed to be much different than its response to a liquidity crisis (Shull 2012). In short, the government is supposed to step in, seize the institution, fire the management, and begin a resolution. There are alternative approaches to resolution, but in the case of the US, there is a mandate to minimize costs to the Treasury (the FDIC maintains a fund to cover some of the losses so that insured depositors are paid dollar-for-dollar). Normally, stockholders lose as do the uninsured creditors-which would have included other financial institutions. It is the Treasury (through the FDIC) that is responsible for resolution. In the midst of the crisis, Treasury Secretary Henry Paulson did ask Congress for funds to deal with the crisis and was provided with about $\$ 800$ billion. However, rather than resolving institutions that were probably insolvent, he first tried to buy troubled assets from them; and after realizing that he would need much more funding to take all the bad assets off their books, he switched to an attempt at recapitalizing them-buying stock in the troubled banks. Yet the crisis continued to escalate-with problems spilling over to insurers of securities, including the "monolines” (that specialized in providing private mortgage insurance) and then to AIG (a huge insurance company that had provided a particularly risky kind of “insurance” called credit default swaps that actually held no reserves against probable losses), to all of the investment banks and finally to the biggest commercial banks.

\section{Deal-Making and Special Purpose Vehicles (SPVs)}

With Congress reluctant to provide any more funding, the Fed and Treasury gradually worked out an alternative approach. In addition to injecting capital into troubled institutions, the Treasury conducted a "stress test” that would supposedly identify institutions likely to fail. However, these tests set thresholds that were far too lax to be of any use. ${ }^{29}$ When an institution did face failure, the Treasury and the Fed-usually represented by the New York Federal

\footnotetext{
${ }^{29}$ Noted risk analyst Christopher Whalen argued that "the stress test is about politics," insisting that the major banks would be insolvent if forced to absorb losses. See Edmund L. Andrews and Eric Dash, "Government Offers Details of Bank Stress Test,” New York Times, Feb 25, 2009 www.nytimes.com/2009/02/26/business/economy/26banks.html. The stress test was conducted in Spring 2009 and was roundly criticized as being too weak. Later, the Treasury admitted that the results were "negotiated" with the banks under examination. See Tom Blumer, "WSJ: Treasury's Stress Test Results 'Negotiated'—Not to Mention Arbitrary and Potentially Corrupt,” News Busters, May 10, 2009 http://newsbusters.org/blogs/tomblumer/2009/05/10/wsj-treasurys-stress-test-results-negotiated-not-mention-arbitrary-poten.
} 
Reserve Bank—would try to make a "deal" to merge the failing institution into another. Often it would be necessary for the Fed to lend to the failing institution for some period while the deal was negotiated. In addition, the Fed created a number of special facilities to provide funding for institutions and also to take troubled assets off their books. By purchasing bad assets, the Fed could conceivably turn a failing bank into a solvent bank. Let us briefly look at this alternative approach.

It must be emphasized that the US Treasury, and indeed the economic team of the Administration of President Obama, was heavily represented by individuals with experience in investment banking. In an interesting article by Davidoff and Zaring (2009), it is argued that the "bailout" can be characterized as "deal-making through contracts," as the Treasury and Fed stretched the boundaries of law with behind-closed-doors hard-headed negotiations. It appears that the government did negotiate with a view to keeping its own risk exposure limited; at the same time, it insisted on large "haircuts" to stockholders' equity but minimal losses to bondholders. It also avoided penalties on bank directors and officers—rarely investigating possible fraud or dereliction of duty. Finally, it avoided "market solutions" in favor of "orderly solutions.” In other words, where markets would shut down an insolvent financial institution, the government would instead find a way to keep the institution operating by merger. The one major exception was Lehman Brothers, as the government allowed the investment bank to fail. Davidoff and Zaring attribute this to an attempt to demonstrate government's willingness to negotiate tough terms.

Further, government relied on the two institutions that are least constrained by the law: the Fed and the Treasury. Throughout the crisis, the government would stretch and flex its authority muscles but would not boldly violate the law. Davidoff and Zaring argue that the federal government was allowed substantial leeway in its interpretation as state courts were not likely to interfere. Further, the Fed has, in the past, interpreted its activities as exempt from "sunshine" laws. ${ }^{30}$ In many ways, this "deal-making” approach that was favored over a resolution by "authority" approach is troubling from the perspectives of transparency and accountability as well for creation of "moral hazard."

\footnotetext{
${ }^{30}$ It literally "took an act of Congress" to get the Fed to release any information concerning its bailout of banks. Senator Bernie Sanders led a heroic effort (joined by long-time Fed critic Congressman Ron Paul and Congressman Alan Grayson) to shine some light on the Fed's bailout activities. As well, Bloomberg successfully sued for release of data under the Freedom of Information Act, forcing the Fed to "dump” 25,000 pages of data.
} 
The other aspect of this approach was unprecedented assistance through the Fed's special facilities created to provide loans as well as to purchase troubled assets (and to lend to institutions and even individuals that would purchase troubled assets). To be sure, in a crisis, the central bank must act as a lender of last resort. But the Fed's actions went far beyond "normal" lending. First, as discussed, it is probable that the biggest recipients of funds were insolvent. We cannot be sure of this because the Treasury's "stress tests" were wimpy; and while the FDIC is responsible for declaring depository institutions insolvent, it had a strong incentive to avoid doing so: its reserves were far too small and it could not risk going to a skeptical Congress to ask for more funding. Second, the Fed provided funding for financial institutions (and to financial markets in an attempt to support particular financial instruments) that went far beyond the member banks that it is supposed to support. It had to make use of special sections of the Federal Reserve Act, some of which had not been used since the Great Depression. And as in the case of the deal-making, the Fed appears to have stretched its interpretation of those sections beyond the boundaries of the law. ${ }^{31}$

We will not go through all of the facilities nor deeply into an examination of the sections invoked to justify the interventions. Instead we will focus on measures of the Fed's interventions. Note, it would not be accurate to call every intervention by the Fed a "bailout." Lending reserves by the Fed to a bank that is short of "liquidity" (reserves needed to meet withdrawals or clearing against other banks) is expected to increase sharply in a crisis. Further, the Fed decided to engage in massive "quantitative easing” (QE) that saw its balance sheet grow from well under $\$ 1$ trillion before the crisis to nearly $\$ 3$ trillion; bank reserves increase by a similar amount as the Fed's balance sheet grows. Such actions do not necessarily indicate a "bailout" as they could be consistent with "liquidity provision” to solvent banks.

Still, QE included asset purchases by the Fed that went well beyond treasuries-the usual asset bought by the Fed when it wants to inject reserves into banks. The Fed bought a lot of mortgage-backed securities in its QE, and while some of these were backed by Fannie and Freddie (hence, ultimately were government liabilities) the Fed also bought "private label" MBSs (not government backed). To the extent the Fed paid more than market price to buy "trashy" assets from financial institutions, that could be construed to be a "bailout." In any case, the Fed's actions went far beyond this—-to include highly unusual actions that are reasonably

${ }^{31}$ See Mehra (2011). 
characterized as a "bailout" of institutions that were probably insolvent. And the volume of such intervention is truly unprecedented-even the Great Crash saw nothing on this scale.

There are two main measures of the total Fed intervention that could qualify as unusual. $^{32}$ The first measure is "peak outstanding” Fed lending summed across each special facility (at a point in time). Several researchers have provided such a calculation-including the GAO, Bloomberg, and the Fed itself_-and all reached a number around \$1.5 trillion. This occurred in December 2008-and represents the maximum outstanding loans made through the Fed's special facilities on any day since the crisis began. As of November 2011, total outstanding Fed loans stood at about $\$ 800$ billion. This measure gives an idea of the maximum “effort” to save the financial system at a point in time, and also some indication of the Fed's total exposure to risk of loss. To be sure, the Fed demands collateral against its loans and it is highly improbable that the Fed would lose anything close to that. Indeed, many of the special facilities were successfully wound down with no losses; the only facilities that are likely to incur big losses are those associated with the rescue of AIG.

The second method is to add up Fed lending and asset purchases through these special facilities over time to obtain a cumulative measure of the Fed's response. To be clear, if the Fed lent $\$ 1$ billion each day, and that was repaid each evening only to be renewed the next morning with another $\$ 1$ billion, that would total $\$ 30$ billion of Fed response over a month. The cumulative measure counts every new loan and every asset purchase made over the course of the life of each special facility. Some of the facilities lasted only a short period, others lasted for two years or more. In some cases, a financial institution borrowed a large amount of funds for a very short period; in other cases, an institution repeatedly borrowed, returning to the Fed many times and remaining in debt for periods up to nearly two years. The cumulative measure would capture such repeated borrowing as continued Fed assistance to the troubled institution. Thus, even if the second institution borrowed less on any given day, the Fed response to help it could sum to a number as large as a short period of assistance through a large loan to an institution that recovered quickly and needed no further help. Finally, another reason to provide a cumulative measure is to indicate just how unprecedented the Fed's intervention was in terms of time. The crisis began in early 2007 (although most of the facilities were created in 2008) and

${ }^{32}$ See Felkerson (2011). 
major Fed interventions continued until 2010 (Fed support for Eurobanks was ramped up again in 2012).

Two University of Missouri-Kansas City graduate students, Andy Felkerson and Nicola Matthews, have carefully summed the cumulative lending and asset purchases through the special facilities, obtaining a total Fed response of more than $\$ 29$ trillion for the period to November 2011 (Felkerson 2011). To put that in perspective, it is over twice as large as a full year's worth of GDP (the measure of annual production and income). For comparison, after the “Great Crash” of 1929, the Fed lent to 123 institutions a total of \$23 million in today’s dollars between 1932-36 (Mehra 2011). You would need to add six zeroes to the Fed's response to the Great Crash to get close to its response to the GFC! The word “unprecedented” really does not adequately describe the Fed's intervention to rescue financial institutions. In the beginning of 2008, the Fed's balance sheet was $\$ 926$ billion, of which 80 percent of its assets were US Treasury bonds; in November 2010, its balance sheet had reached \$2.3 trillion, of which almost half of its assets were MBSs. Over the next year, it ramped-up its purchases of treasuries (and reduced its use of the special facilities) so that its balance sheet was close to \$3 trillion-three times larger than it was on the eve of the crisis.

And still there is no end in sight.

One final comment: many of the Fed's special facilities used "special purpose vehicles" created to buy assets or to make loans. Note the creation of SPVs by banks had played a big role in causing the GFC—-banks created SPVs to move risky assets off their balance sheets so that they would not need to hold capital, and so that government regulators and supervisors would not see the risk. This allowed banks to take on much more risk and more leverage in an effort to increase profits. In an ironic twist, the Fed followed the example set by banks as it created SPVs to subvert constraints written into the Federal Reserve Act.

As discussed above, there is no problem with Fed lending to member banks to stop a run. It is a bit more problematic to lend to insolvent member banks, but still legal. In "unusual and exigent” circumstances, the Fed is free to go much farther under Section 13(3) of the Federal Reserve Act; although as Mehra (2011) explains, the bar is still high. In such circumstances, the Fed can lend to individuals, partnerships, and corporations at a discount if they are unable to secure adequate credit from other banks. Further, it must lend against indorsed or secured assets. But here's the problem with the Fed's invocation of this section to justify its intervention: it created SPVs and then lent to them so that they could buy troubled 
assets. In other words, it financed the purchase of an asset, rather than making a loan. In most cases, its loan was to its own SPV, and not to the party that needed assistance. In some cases, the loans were not technically "discounts," and were not against endorsed assets (the SPVs owned no assets until they got the loans so they could buy troubled assets); and in most cases, the beneficiaries could have obtained loans from other banks, albeit at higher interest rates. In all these respects, the law was "stretched" if not subverted. In all those respects, this looks like "bailout" and not "liquidity provision."

The volume of Fed assistance of questionable legality under 13(3) was very large. Its four SPVs lent approximately $\$ 1.75$ trillion (almost 12 percent of the total Fed cumulative intervention). In addition, its questionable loan programs that either lent against ineligible assets or lent to parties that were not troubled total $\$ 9.2$ trillion (30 percent of the total intervention). In sum, of the $\$ 29$ trillion lent and spent by fall 2011, over 40 percent was perhaps improperly justified under section 13(3). ${ }^{33}$

\section{Incentives}

With the "deal-making" and "bailout" approaches of the Fed and Treasury, it is unlikely that financial institutions have learned anything from the crisis-except that risky behavior will lead to a bailout. In the Savings and Loan crisis of the 1980s, many institutions were shut down and resolved, and more than a thousand officers in top management served jail time. In the current crisis, no top officer has been prosecuted, much less jailed. Banks have been slapped on the wrists with some fines - usually without being forced to admit wrong-doing.

Critics like Walker Todd have long argued that continued expansion of government's "safety net" to protect "too big to fail” institutions not only runs afoul of established legal tradition, but also produces perverse incentives and competitive advantages (Todd 2002). The largest institutions enjoy "subsidized" interest rates—-their uninsured liabilities have de facto protection because of the way the government (Fed, FDIC, OCC, and Treasury) props them up, eliminating risk of default on their liabilities (usually only stockholders lose). The "dealmaking” approach described above extended the principle of lender of last resort activities to entirely novel areas — protecting creditors of even shadow banks and, as discussed, favoring bond holders while forcing stockholders and securities holders (and defrauded homeowners) to

${ }^{33}$ Author's calculations based on Mehra (2011) and Felkerson (2011). 
take losses. As William Black argues, these "too big to fail" institutions are really "systemically dangerous institutions" (SDIs), mostly run as "control frauds" to enrich top management. ${ }^{34}$ As long as they remain in business, they destroy economic value - not just the capital value of the firm, but the financial and real wealth of the economy as a whole. Total financial losses that can be attributed to the GFC already exceed $\$ 10$ trillion and will eventually sum to much more. And, of course, that does not include the "real" economic losses—nearly 10 million jobs in the US alone.

With all the government support, most of the financial institutions have so far survived the crisis. While they are reluctant to quickly resume the practices that caused the crisissubprime lending, securitization of junk assets—-they did not suffer much from them. It is probable that if the economy and financial sector were to recover, risky practices would come back. ${ }^{35}$ Further, and more alarmingly, the financial sector bounced right back to taking 40 percent of corporate profits, to pay-outs of huge bonuses to top management and traders, and to accounting for 20 percent of value-added toward national GDP.

No significant financial reforms made it through Congress. All of this is in sharp contrast to the 1930s New Deal reform. Half of all banks failed that time around, and most of the survivors were taken over by the government. Management was replaced. The Pecora Commission was given relative free reign to investigate the causes of the crisis and to go after the crooks. Widespread defaults and bankruptcies wiped out a lot of the private sector's debt. The financial sector was down-sized and rendered unimportant for several decades. World War II led to budget deficits equal to 25 percent of GDP, and government debt grew much faster than income so that it flooded private portfolios with safe and liquid assets. The New Deal provided jobs and then a safety net for those who fell through the cracks of the “Golden Era” of US economic growth. The "managerial, welfare-state” version of capitalism emerged to replace finance capitalism. This time, after the GFC, we still have the modern version of finance capitalism - money manager capitalism--somewhat worse for the wear, but still pumping up commodities market bubbles and the stock market.

\footnotetext{
${ }^{34}$ See William K. Black, "The Two Documents Everyone Should Read to Better Understand the Crisis,” The Huffington Post, February 25, 2009 http://www.huffingtonpost.com/william-k-black/the-two-documentseveryon_b_169813.html.

${ }^{35}$ There are already some reports that subprime MBSs are making a comeback. See Jillian Berman, "Subprime Mortgage Bonds Back In Fashion,” The Huffington Post, February 17, 2012 www.huffingtonpost.com/2012/02/16/subprime-mortgage-_n_1282157.html.
} 


\section{CONCLUSIONS AND PROSPECTS}

In his General Theory, J.M. Keynes argued that substandard growth, financial instability, and unemployment are caused by the fetish for liquidity. The desire for a liquid position is antisocial because there is no such thing as liquidity in the aggregate. The stock market makes ownership liquid for the individual "investor," but since all the equities must be held by someone, my ability to sell-out depends on your willingness to buy-in.

Over the past several decades, the financial sector, taken as a whole, moved into shortterm finance of positions in assets. This is related to the transformation of investment banking partnerships that had a long-term interest in the well-being of their clients to publicly held, pump-and-dump enterprises whose only interest is the well-being of top management. It also is related to the rise of shadow banks that appeared to offer deposit-like liabilities but without the protection of FDIC. It is related to the Greenspan "put" and the Bernanke "great moderation" that appeared to guarantee that all financial practices—no matter how crazily risky — would be backstopped by Uncle Sam. And it is related to very low overnight interest rate targets by the Fed (through to 2004) that made short-term finance cheap relative to longer-term finance.

All of this encouraged financial institutions to rely on insanely short short-term finance. Typically, financial institutions were financing their positions in assets by issuing IOUs with a maturity of mere hours. Overnight finance was common—through repos, asset-backed commercial paper, and deposit-like liabilities.

On the other hand, the assets were increasingly esoteric positions in mark-to-myth structured assets with indeterminate market values—indeed, often with no real markets into which they could be sold. Further, many of these assets had no clearly defined income flowsvirtually by definition, a NINJA loan (no income, no job, no assets) has no plausible source of income to service the debt. That is just the most outlandish example—but much of the "asset backed commercial paper" (ABCP) had no reliable source of sufficient income to service the liabilities issued. US debt-to-GDP ratios reached 500 percent-there was a dollar of income to service $\$ 5$ of debt. Inevitably, the short-term liabilities of financial institutions could not be serviced —and they could be rolled over only so long as the myths were maintained.

As soon as some holders of these risky assets wondered whether they would be repaid, the whole house of cards collapsed. And that largely took the form of one financial institution 
refusing to "roll over" another financial institution's short term IOUs. Four years and trillions of lost dollars of wealth later, we are still in crisis. ${ }^{36}$

Since 2008, we've had a steady stream of recommendations concerning what to do to remedy the problem. Most of the "reforms" suggested misidentify the problem, or have no political viability. The Dodd-Frank legislation that was finally passed is toothless and will do little to remedy current problems or to prevent future crises. It does have one positive effect: many of the Fed's bailout actions last time around are now illegal—but where there's a will, there's a way to get around such restrictions (Ricks 2011). Still, so far as legislative reforms go, the best we can hope for is that the next crash will open the possibility for real reform.

In an interesting piece, former Treasury advisor Morgan Ricks has offered a proposal that is thoughtful, coming down squarely in the middle of those who want to tweak a few more regulations and those who want to close down the biggest institutions. ${ }^{37}$

Morgan quotes University of Chicago's Douglas Diamond that "financial crises are always and everywhere about short-term debt." Financial crises occur because of this conflict between the desire for liquidity by individuals, and the impossibility of liquidity for society as a whole. Think of it this way: all assets—financial or real—must find homes, so we cannot all get out of them simultaneously. In a crisis, that is precisely the problem: we all try to sell out, but cannot. In the GFC, holders of the very short-term liabilities of financial institutions rationally decided to get out. A lot of the analyses of a run to liquidity rely on the supposition of irrationality, but there was nothing irrational about the run out of short-term financial institutions liabilities in 2008. These institutions were holding bad assets. The suspected insolvency led immediately to a liquidity crisis as creditors refused refinance. So what is Morgan Ricks’ solution? “Term out:” force financial institutions that take risky bets to finance their positions in assets by issuing longer-term liabilities. In that case, there is no easy way to "run out." The creditors are locked into the crazy bets made by the debtors. Maybe they'll pay off; maybe they won't.

Turning to investment banks, before 1999 they used partner's money, with low leverage. But then they went public and adopted a new business model: maximize share prices—and top management was rewarded with bonuses for doing so. To align interests, part of their

\footnotetext{
${ }^{36}$ For discussion of the economic fallout, see FCIC (2011): Chapter 21.

${ }^{37}$ See Morgan Ricks, “A Former Treasury Adviser On How To Really Fix Wall Street,” The New Republic, December 17, 2011 www.tnr.com/print/article/politics/98659/wall-street-term-out-panic.
} 
compensation was in the form of stock options. They greatly increased leverage and moved to short-term finance. The investment banks made people like Hank Paulson and Bob Rubin richand then the top management obtained positions in Treasury which helped to back-stop the banks’ risky positions. The so-called "Greenspan put" and the "Bernanke great moderation" convinced markets that these risky short term liabilities issued by investment banks betting in complex collateralized debt obligations squared and cubed were actually as safe as FDICbacked bank deposits. And then when the whole thing collapsed, the Fed and Treasury really did bail them out— to the tune of tens of trillions of dollars.

Ricks' Solution: segregate financial institutions into two mutually exclusive camps. One is subject to regulation and supervision of the asset side of its balance sheet. It gets to issue insured deposits. As these are payable on demand, they are by nature short-term, and are the primary medium of exchange and means of payment that is necessary in any monetary economy. It's a safe and sound camp that restores the protection afforded by Glass Steagall.

The other camp consists of all those who are not subject to such supervision and regulation. They are pretty much free to buy any assets, but they must "term out"-financing by using long-term liabilities. And they cannot issue anything that purports to be similar to a deposit. In short, they offer an experience that is not suitable for everyone. This will reduce the problem of short-termism with respect to financing positions in risky assets. It also mitigates the complaint about excessive regulation — any institution that hates regulation can avoid it almost completely by funding long-term. And it makes the payments system safe by keeping the risky operators out. Now, will that long-term funded and unregulated partition of the financial sector periodically crash and burn? Yes it will, and those that take excessive risks will fail.

The Fed's bailouts of Wall Street certainly stretched and might have violated both the law as established in the Federal Reserve Act (and its amendments) and also well-established procedure. There is a long tradition in the Fed of a distinction between continuous versus emergency borrowing at the Fed. Briefly, the Fed is permitted to lend (freely as Bagehot recommended) to resolve a liquidity crisis, but it has long refused to provide "continuous" lending. Here the idea is that the Fed should stop a liquidity crisis, but then solvent financial institutions should quickly return to market funding of their positions in assets. The crisis started in 2008. Four years later the Fed is still lending and at "subsidized" (below market) interest rates. 
The Fed is also generally prohibited from lending to "nonbank" financial institutionswhat we now call shadow banks that are not members of the Federal Reserve System and that do not issue FDIC insured deposits. However, there is an exception granted in the Fed's “13(3)” provisions that allow the Fed to lend in "unusual and exigent" conditions. Certainly the crisis in 2008 qualifies as unusual and exigent. However, as discussed, the 13(3) restrictions are tight, and the Fed seems to have stretched the law. Some might object that while there was some questionable, possibly illegal activity by our nation’s central bank, wasn’t it justified by the circumstances?

The problem is that this "bailout" validated the questionable, risky, and in some cases illegal activities of top management on Wall Street, those running the "control frauds" in the terminology of my colleague, Bill Black. ${ }^{38}$ By agreement of most researchers, the effect of the bailout has been to continue, if not increase, the distribution of income and wealth flowing to the top one-tenth of one percent. It has kept the same management in control of the worst serial abusers_-Goldman, Bank of America, Citigroup, and JPMorgan-Chase-as they paid record bonuses to top management. Some of their fraudulent activity has been exposed, and the top banks have paid numerous fines for bad behavior. Yet, Washington has been seemingly paralyzed-Eric Holder, US Attorney General, has not begun a single investigation of criminal behavior by top management. ${ }^{39}$

What should have been done? Bagehot's recommendations are sound, but must be amended. Any of the "too big to fail” financial institutions (what Black calls "systemically dangerous institutions”) that needed funding should have been required to submit to Fed oversight. Top management should have been required to submit resignations as a condition of lending (with the Fed or Treasury holding the letters until they could decide which should be accepted). The Attorney General's office should have been called in to investigate all top management, to prosecute crimes, and to pursue jail time for convictions. Short-term lending against the best collateral should have been provided, at penalty rates. A comprehensive "cease and desist” order should have been enforced to stop all trading, all lending, all asset sales, and all bonus payments. The FDIC should have been called-in (in the case of institutions with insured deposits), but in any case the institutions should have been dissolved according to

\footnotetext{
${ }^{38}$ See Black (2005).

${ }^{39}$ Indeed, he worked with 49 of the State Attorneys General to "resolve" the foreclosure fraud crisis in a manner that avoided criminal investigation. See L. Randall Wray, "State AGs Cave to Banksters," EconoMonitor (blog), February 9, 2012 http://www.economonitor.com/lrwray/2012/02/09/state-ags-cave-to-banksters-2/.
} 
existing law: at least cost to Treasury and to avoid increasing concentration in the financial sector.

This would have left the financial system healthier and smaller; it would have avoided the moral hazard problem that has grown over the past three decades as each risky innovation was validated by a government-engineered rescue; and it would have reduced the influence that a handful of huge banks have over policy-makers in Washington. 


\section{REFERENCES}

Bernanke, Ben S. 2004. “The Great Moderation.” Speech given at the meetings of the Eastern Economics Association. Washington, DC: February 20, 2004. http://www.federalreserve.gov/boarddocs/speeches/2004/20040220/default.htm

Black, William. 2005. The Best Way to Rob a Bank is to Own One; How Corporate Executives and Politicians Looted the S\&L Industry. Austin, TX: University of Texas Press.

D’Arista, Jane. 2001. “The Role of the International Monetary System in Financialization.” Paper prepared for the Political Economy Research Institute (PERI) conference on Financialization of the Global Economy, December 7-8. Amherst, MA: University of Massachusetts. http://www.peri.umass.edu/fileadmin/pdf/financial/fin_darista.pdf

Davidoff, Steven M. and David Zaring. 2009. "Regulation by Deal: The Government's Response to the Financial Crisis” Administrative Law Review 61 (3): 463.

Felkerson, James. 2011. “29,000,000,000: A Detailed Look at the Fed’s Bailout by Funding Facility and Recipient.” Working Paper No. 698. Annandale-on-Hudson, NY: The Levy Economics Institute of Bard College.

Financial Crisis Inquiry Commission. 2011. The Financial Crisis Inquiry Report. Superintendent of Documents. Washington, DC: US Government Printing Office.

Galbraith, John Kenneth. 2009 [1954]. The Great Crash, 1929. New York, NY: Houghton Mifflin Harcourt.

Godley, Wynne and L. Randall Wray. 1999. “Can Goldilocks Survive?” Policy Note 1999/4. Annandale-on-Hudson, NY: The Levy Economics Institute of Bard College.

Hilferding, Rudolf. 1981 [1910]. Finance Capital: A Study of the Latest Phase of Capitalist Development. London: Routledge and Kegan Paul.

Kelton, Stephanie and L. Randall Wray. 2004. "The War on Poverty after 40 Years: A Minskyan Assessment.” Public Policy Brief No. 78. Annandale-on-Hudson, NY: The Levy Economics Institute of Bard College.

Kregel, Jan. 2008. "Minsky's Cushions of Safety: Systemic Risk and the Crisis in the US Subprime Mortgage Market.” Public Policy Brief No. 93. Annandale-on-Hudson, NY: The Levy Economics Institute of Bard College.

Mehra, Alexander. 2011. "Legal Authority in Unusual and Exigent Circumstances: The Federal Reserve and the Financial Crisis." University of Pennsylvania Journal of Business Law 13 (1): 221.

Minsky, Hyman P. 1965. “The Role of Employment Policy.” In Poverty in America. Margaret S. Gordon, ed. San Francisco, CA: Chandler Publishing Company. 
— 1991. “The Transition to a Market Economy.” Working Paper No. 66. Annandale-onHudson, NY: The Levy Economics Institute of Bard College.

— 1996. "Uncertainty and the Institutional Structure of Capitalist Economies.” Working Paper No. 155. Annandale-on-Hudson, NY: The Levy Economics Institute of Bard College.

Minsky, Hyman P. and Charles Whalen. 1996. "Economic Insecurity and the Institutional Prerequisites For Successful Capitalism.” Working Paper No. 165. Annandale-onHudson, NY: The Levy Economics Institute of Bard College.

Moynihan, Daniel Patrick. 1965. The negro family: The case for national action. Office of Policy Planning and Research, US Department of Labor. http://www.dol.gov/oasam/programs/history/webid-meynihan.htm.

Nersisyan, Yeva and L. Randall Wray. 2010. “The Global Financial Crisis and the Shift to Shadow Banking.” Working Paper No. 587. Annandale-on-Hudson, NY: The Levy Economics Institute of Bard College.

Papadimitriou, Dimitri B. and L. Randall Wray. 1998. “The Economic Contributions of Hyman Minsky: Varieties of Capitalism and Institutional Reform.” Review of Political Economy 10(2): 199-225.

Ricks, Morgan. 2011. "Regulating Money Creation After The Crisis.” Harvard Business Law Review 1 (18).

Sen, Sunanda. 2010. “The Meltdown of the Global Economy: A Keynes-Minsky Episode?” Working Paper No. 623. Annandale-on-Hudson, NY: The Levy Economics Institute of Bard College.

Shull, Bernard. 2012. “Too Big To Fail: Motives, Countermeasures, and the Dodd-Frank Response.” Working Paper No. 709. Annandale-on-Hudson, NY: The Levy Economics Institute of Bard College.

Strange, Susan. 1997. Casino Capitalism. Manchester, UK: Manchester University Press.

Todd, Walker F. 2002. "Central Banking in a Democracy: The Problem of the Lender of Last Resort.” in Patricia A. McCoy, ed. Financial Modernization after Gramm-Leach-Bliley. Newark NJ: Lexis/Nexis (Matthew Bender \& Company, Inc.).

US Senate. 2011. Permanent Subcommittee on Investigations. Committee on Homeland Security and Government Affairs. Wall street and the financial crisis: Anatomy of a financial collapse. Report prepared by Carl Levin and Tom Coburn. 112th Cong., 1st sess. www.ft.com/cms/fc7d55c8-661a-11e0-9d40-00144feab49a.pdf. 
Veblen, Thorstein. 1958. The Theory of Business Enterprise. New York, NY: A Mentor Book, The New American Library of World Literature, Inc.

Wray, L. Randall. 1999. "Surplus Mania: A Reality Check.” Policy Note 1999/3. Annandale-onHudson, NY: The Levy Economics Institute of Bard College.

— . 2003. "Can a Rising Tide Raise All Boats? Evidence From the Kennedy-Johnson and Clinton-Era Expansions.” In New Thinking in Macroeconomics: Social, Institutional and Environmental Perspectives. Jonathan M. Harris and Neva R. Goodwin, eds. Northampton, Mass.: Edward Elgar.

—. 2007. "Fixed and Flexible Exchange Rates and Currency Sovereignty.” Working Paper No. 489. Annandale-on-Hudson, NY: The Levy Economics Institute of Bard College.

— 2008a. “Financial Markets Meltdown: What Can We Learn From Minsky?” Public Policy Brief No. 94. Annandale-on-Hudson, NY: The Levy Economics Institute of Bard College.

— 2008b. "The Commodities Market Bubble: Money Manager Capitalism and the Financialization of Commodities.” Public Policy Brief No. 96. Annandale-on-Hudson, NY: The Levy Economics Institute of Bard College.

—. 2009. "The Rise and Fall of Money Manager Capitalism: A Minskyan Approach.” Cambridge Journal of Economics 33 (4): 807-828. 